\title{
MAKTABAH SYUMILA NU FIHA AND MAKTABAH SYAMILAH: DIGITAL TRANSFORMATION AND CONTESTATION IN PESANTREN
}

\author{
Kardi \\ State Islamic Institute Ponorogo \\ Jl. Pramuka 156 Ponorogo Jawa Timur, 63471 \\ E-mail:kardi@iainponorogo.ac.id.
}

Al Makin

State Islamic University of Sunan Kalijaga

Jl.Marsda Adisucipto Yogyakarta, 55281

E-mail:makin@uinsuka.ac.id

Anis Masruri

State Islamic University of Sunan Kalijaga

Jl. Marsda Adisucipto Yogyakarta, 55281

E-mail:anismasruri@uinsuka.ac.id

\begin{tabular}{c|c|c}
\hline Received: & Revised: & Approved: \\
$2 / 06 / 2020$ & $14 / 11 / 2020$ & $15 / 12 / 2020$ \\
\hline
\end{tabular}

DOI :https:/ / doi.org/10.32332/akademika.v25i2.3047

\section{(c) (1) (-) \\ Maktabah Syumila NU Fiha And Maktabah Syamilah : Digital Transformation and Contestation In Pesantren Licensed Under a Creative Commons Attribution- ShareAlike 4.0 International License.}

\begin{abstract}
This article aims to describe the Pesantren's response to the use of digital applications of classical books as open sources of education. Starting from the phenomenon of using al-maktabah sya> milah software in Pesantren Salaf (traditional Islamic boarding schools) where they have a scientific tradition of using printed Kitab Kuning (Islamic classical books) for quite a long time. The presence of a digital media transformation called almaktabah sya>milah is an alternative for searching information on classical books in Pesantrens. Then, this article questions on the emergence of al-maktabah syu> mila NU fi>ha software at the Pesantren Assalafiyyah, Mlangi, Sleman, Yogyakarta in response to the presence of al-maktabah sya>milah. Syu>mila NU containing digital books by mu'tabar ulama taught in Pesantren Salaf, while Syamilah containing books by Arabic ulama allegedly carrying Wahhabi understanding. This has led to a contestation between the two Kitab Kuning digital applications in the Pesantren Salaf. This article uses an interpretive qualitative descriptive approach from library document data, multi-site, and software. The author analyzes the information on both the software and the related web. Maktabah syu> mila NU fi> ha software development is defensive which aims to fortify the Pesantren from the influence of the syamilah maktabah understanding which brings Wahhabi; a intolerant, apolitical, anti-tradition, and transnational understanding. The presence of this application appeared various responses from the
\end{abstract}


pesantrens. Pesantren Hidayatul Mubtadi'in Lirboyo, Kediri tends to be skeptical whether Pesantren Assalafiyyah Mlangi, Yogyakarta is more neutral, and Pesantren Salafiyyah Syafi" iyyah Sukorejo, Situbondo tends to be moderate and optimistic. This response is inseparable from the pesantren policy which is contained in the board" $\mathrm{s}$ rules for the use of electronic devices.

Keywords: Pesantren (Islamic boarding schools), Kitab Kuning software, digital applications, maktabah sya>milah, maktabah syu>mila.|

\section{A. Introduction}

Information and Communication Technology (ICT) is developing rapidly and practically in the reality of life of which not value free. In addition, others think that technology was initially neutral ${ }^{1}$. These values can be in the form of authority, ideology, and identity of the initiator driving to contestation among digital applications ${ }^{2}$. Contestation means matches competitions, battles, and etc. Contestation in the digital world is also very possible in pesantrren ${ }^{3}$. One of them is that contestation occurs because of digital transformation. According to the Big Indonesian Dictionary, contestation means controversy, debate, or how to get support from the people ${ }^{4}$. Antje Wiener strengthens the contest with 4 features that must be fulfilled from a contestation phenomenon, namely value, shape, segment, and cycle ${ }^{5}$. Ian G. Barbour added that the prerequisites for integrating science with religion are 4 elements, namely conflict, independence, dialogue, and integration ${ }^{6}$. Their encounter between them have ordained the study of interconnection integration which was expanded into a multidisciplinary, interdisciplinary, trans-disciplinary scientific study in the contemporary era?.

This phenomenon is reflected in the emergence of the maktabah syu>mila NU fi>ha software as a source of information on kitab kuning digital by mu tabar scholars taught at the Pesantren Assalafiyyah Mlangi, Sleman, Yogyakarta. The software was built by a

1 Boaz Miller, "Is Technology Value-Neutral?," Science, Technology, E Human Values 46, no. 1 (January 1, 2021): 53-80, accessed March 2, 2021, https://doi.org/10.1177/0162243919900965.

2 Fatima Zafar Baig et al., "Power, Ideology and Identity in Digital Literacy: A Sociolinguistic Study," International Journal of English Linguistics 9, no. 4 (July 3, 2019): 252, accessed January

4 ,

2021, http://www.ccsenet.org/journal/index.php/ijel/article/view/0/40015. Lihat juga, Luciana Pangrazio, "Reconceptualising Critical Digital Literacy," Discourse: Studies in the Cultural Politics of Education 37, no. 2 (March 3, 2016): 163-174, accessed January 4, 2021, https:/ / www.tandfonline.com/doi/full/10.1080/01596306.2014.942836.

3 Ali Ja" far, "Literasi Digital Pesantren: Perubahan Dan Kontestasi," Islamic Review: Jurnal Riset dan Kajian Keislaman 8, no. 1 (2019): 17-35.

4 "Hasil Pencarian - KBBI Daring," accessed January 12, 2021, https://kbbi.kemdikbud.go.id/entri/kontestasi.

5 Antje Wiener, A Theory of Contestation, SpringerBriefs in Political Science (Berlin, Heidelberg: Springer Berlin Heidelberg, 2014), accessed July 30, 2019, http:/ /link.springer.com/10.1007/978-3-642-55235-9.

${ }^{6}$ Amin Abdullah, Multidisiplin, Interdisiplin, E Transdisiplin: Metode Studi Agama E Studi Islam Di Era Kontemporer, Cet.ke-2. (Yogyakarta: IB Pustaka, 2020).

7 F. LeRon Shults, "When Science Meets Religion: Enemies, Strangers or Partners?," Theology Today 58, no. 3 (October 2001): 434-435, accessed February 27, 2021, http://journals.sagepub.com/doi/10.1177/004057360105800318. 
student from the pesantren with the aim of fortifying the faith of ahl al-sunnah wa aljama > ,ah al-nahdliah (asawaja NU) from the intolerance of the commitment to diversity, diversity, and nationality in Indonesia. This is confirmed in the statement of informant held by Wafiq (2020) as follows. ${ }^{8}$

"...Maktabah Syamilah software contains books which are dominated by Wahabi scholars. The reason for the developer of Syumila NU to make a new application that is more in line with the struggle of the pesantren in fortifying themselves from the students from ideas that are not in line with the spirit of Islam ahlus sunnah wal jama'ah annahdliah."

As written by Abdul Wahid, the maktabah sya>milah software which comes from Saudi Arabia tends to be radical and carries a transnational mission, the truth claim that the group is the most correct whereas others are wrong 9 . This is the beginning of the contestation of digital applications in the area of religious ideology in Islam so that the development of information and communication technology requires reconceptualization of critical digital literacy, as stated by Pangrazio ${ }^{10}$ that digital literacy always requires redesign considering the character of the user who continues to develop in the digital native era which has the a very fast digital practice. The digital transformation of the analog format is a phenomenon of digital literacy culture in the last two decades which has had a binary and paradoxical influence ${ }^{11}$. There are positive and negative impacts for the development of education in pesantren. The trend of applications containing kitab kuning digital is circulating in various pesantrens both online and offline. This digital tool can help overcome problems in distance learning system (PJJ), such as in the midst of difficult conditions such as the Covid 19 pandemic.

However, in practice, the use of digital applications of classical books in Islamic boarding schools still not can be optimized yet and experiences many obstacles. Among them is the problem of pesantren regulations in using electronic devices, some of the pesantren salaf used by the author, as a sample in describing the response to the presence of the kitab kuning digital application at pesantren salaf. The pesantren are Pesantren Assalafiyyah Mlangi, Yogyakarta; Pesantren Hidayatul Mubtadi" in, Lirboyo, Kediri; and Pesantren Salafiyyah Syafi" iyyah Sukorejo, Situbondo. The data were collected through observation, interviews, and documentation. This can be seen from the regulatory policy for the use of digital applications. Among them are skeptical, neutral, and optimistic. The skeptical response, pesantren tends to be pessimistic and a

priori towards the use of digital applications in pesantren. Meanwhile, a neutral attitude stands between skepticism and optimism that tends to be moderate in responding to the presence of the kitab kuning digital application in pesantrens.

8 Interview with Wafiq (Developer of Maktabah Syumila NU Fiha), 13 September 2020.

${ }_{9}^{9}$ Abdul Wahid and Marizakertaningtyas Marizakertaningtyas, "Efektifitas Software Dan Aplikasi Syumila Nu 1.0 Untuk Penguatan Ideologi Pesantren an-Nur Al-Huda Dari Ancaman Paham Islam Transnasional," JURNAL TEKNOLOGI INFORMASI: Teori, Konsep, dan Implementasi 9, no. 1 (2018): 10.

10 Pangrazio, "Reconceptualising Critical Digital Literacy," 164.

11 Henrik Wimelius et al., "A Paradoxical Perspective on Technology Renewal in Digital Transformation," Information Systems Journal 31, no. 1 (2021): 198-225, accessed March 2, 2021, https://onlinelibrary.wiley.com/doi/abs/10.1111/isj.12307. 


\section{B. General Concepts of Digital Transformation and Contestation}

The development of information and communication technology has led to changes in information seeking behavior from printed to non-printed materials or from manual to digital materials. Digital words and their usage have also been affected by this change. The word "Digital" taken from the English "digit" means that the number from 0 and 1 has many variants of the word, such as digitalization, digitize, digitalize, digitization. Each has a different meaning with a different usage. However, cases in Indonesia, those often overlap in the use of the terms "digitalisasi" and "digitisasi". Both are interpreted as transforming information from analog (manual) to digital format. Nevertheless, according to Colleen Chapco-Wade ${ }^{12}$, "digitalisasi" is the use of digital technology as well as the use of digital clocks, while "digitisasi" is the process of transferring media from printed to non-printed (digital). However, practically in Indonesian, the word "digitalisasi" is often used to mean all processes of using digital systems, as defined by KBBI online.

In addition to the term "digitalisasi" to describe media transfer activities, some use the term "transformation" in showing the process of changing from printed material to digital. This transformation is carried out to provide various advantages in terms of energy, cost and space. Digitizing printed materials saves energy in organizing all collections. Likewise, it can save costs and space. This can be exemplified in a library in managing many ancient books, in addition to requiring sufficient space, but also extra property and care to maintain the strength of the condition of the book. Digitalisasi provides an effective and efficient solution, in addition to its advantages and disadvantages. The role of internet expansion in the development of digital applications is very significant, resulting in the emergence of digital applications that are easily accessible together (ubiquites) easily and cheaply. There are many Islamic digital applications that can be accessed for free and open. Such reference sources are often known as open educational resources (OER) ${ }^{13}$. Thus, digital transformation and digitization are something different. Digitalisasi and Digitisasi are talking about technology, while digital transformation is talking about customers ${ }^{14}$.

\section{Libraries, Pesantrens, and the Kitab Kuning Tradition}

Pesantren Salaf are long-standing educational institutions with a kitab kuningbased learning system (yellow paper format). The learning method is also unique with

${ }^{12}$ Colleen Chapco-Wade, "Digitization, Digitalization, and Digital Transformation:

What" s the Difference?," Medium, last modified October 21, 2018, accessed February 12, 2020, https://medium.com/@colleenchapco/digitization-digitalization-and-digital-transformationwhats-the-difference-eff1d002fbdf.

13 Hong Lin, "From Paper to Digital: Undergraduate Students' Perceptions with Open Educational Resources" (Presented at the Society for Information Technology \& Teacher Education International Conference, Association for the Advancement of Computing in Education (AACE), 2019), 1207-1215, accessed February 26, 2021, https://www.learntechlib.org/primary/p/207798/.

${ }^{14}$ Natalja Verina and Jelena Titko, "Digital Transformation: Conceptual Framework," in Proc. of the Int. Scientific Conference "Contemporary Issues in Business, Management and Economics Engineering" 2019", Vilnius, Lithuania, 2019, 9-10.; Baca, Saul J. Berman, "Digital Transformation: Opportunities to Create New Business Models," Strategy \& Leadership 40, no. 2 (March 2, 2012): 16-24, accessed February 28, 2021, https://www.emerald.com/insight/content/doi/10.1108/10878571211209314/full/html.; Behnam Tabrizi et al., “Digital Transformation Is Not About Technology" (n.d.): 6. 
face-to-face systems in the wetonan, bandongan, and sorogan formats which tend to be one way traffic (only kiai/ ustadz are active) in the communication system. That means that learning is based on a classical learning system using kitab kuning printed media by means of the kiai/ ustadz reading the book and the students affixing meaning to the book. This system is carried out face-to-face in one assembly. The books studied also have the sanad ulama "salaf al-shalih 'aahl al-sunnah wa al-jama'ah" which are mu" tabar and $m u^{\prime \prime}$ tamad in pesantren salaf. There are several levels of Kitab kuning taught in pesantren, namely the basic, intermediate (moderate), and high (advanced) levels. Kitab Kuning at the basic level is as in the following table list:

Table 1: Basic Book taught at the Pesantren Salaf

\begin{tabular}{cll}
\hline NO & \multicolumn{1}{c}{ BOOK } & FIELD \\
\hline 1. Al-Jurumiyah & Nahwu \\
2. Amtsilah al-Tashrifiyah & Fiqh \\
3. Mustholah al-Hadits & Hadith \\
4. Arba'in Nawawi & Hadith \\
5. Al-Taqrib & Fiqh \\
6. Ta" limul Muta'alim & Morals \\
7. Aqidatul Awam & Creed \\
8. Safinatu Najah & Basic Science of Fiqh \\
\hline \multicolumn{2}{l}{ Source: Author Synthesis }
\end{tabular}

Source: Author Synthesis

The list of book names is also available in digital format on the Maktabah syu>mila NU fi>ha Software. The learning tradition of using Kitab Kuning is challenged to accept or reject the presence of various digital applications of Kitab Kuning in pesantrens. This consequence is a risk that must be faced by pesantren which have entered the era of the industrial revolution ${ }^{15}$. Among other things is that the presence of digital applications such as al-maktabah asy-sya>milah in pesantrens can actually become virtual libraries to become new treasures for pesantrens in obtaining alternative sources of information more effectively and efficiently. However, the presence at the Pesantren Salaf has not received a good response due to the issue of the mission of spreading Wahhabi ideology. This can be seen in the existence of the books of the Wahabi Arabic ulama" s works on the digital application. Then, it prompted one of the santri (student of pesantren) from the Pesantren Assalafiyyah Mlangi, Sleman, Yogyakarta to build an application called al-maktabah syu>mila NU fi>ha which contained a Kitab Kuning digital in the style of the pesantren salaf.

The naming of the two applications is similar in the use of the term al-maktabah which means library. Both applications can be a collection of digital libraries in pesantrens. In addition, there are many other digital applications, each of which is unique $^{16}$. There are also the emergence of various other digital applications such as social media, online meeting applications (such as zoom meetings) so that if they encounter problems in face-to-face learning, santris can actually attend recitation

15 Mahyudin Ritonga, Ahmad Lahmi, and Rosniati Hakim, “The Existence of Yellow Books (Kitab Kuning) as the Sources of Islamic Studies at Islamic Boarding Schools Within the Industrial Revolution Dialectics," Int. J. Psychosoc. Rehabil 24, no. 8 (2020): 3516-3523.

${ }^{16}$ Can be searched on google search on this page "74 Maktabah Raqmiah Maftuhah Min Asyhur Al-Maktabah Al-Iliktruniah," Darul Qurra, n.d., accessed April 9, 2020, http://darulqurra.edu.pk/74. 
through on-screen learning (online) ${ }^{17}$.

Digital power is an interesting segment of the power relation discourse over analog (manual) systems in the development and use of digital technology in pesantrens is also an interesting phenomenon in the battle arena against the tradition of the printed form of kitab kuning as a hallmark of pesantren salaf18. Pesantrens in facing a challenge of the expansion of digital technology is certainly far from the tradition or scientific culture in pesantren that has been passed down from generation to generation to Islamic classical sources in printed format. Digital literacy provides opportunities for santris to gain insight more quickly, easily, and practically ${ }^{19}$. It is time for pesantren to gain freedom of thought in facing the increasing complex challenges of the times, as said Hatim Ghazali and Abdul Malik, who researched the existence of Pesantren $\mathrm{Ma}^{\prime \prime}$ had "ali Sukorejo in freedom of opinion dealing with problems in society such as issues of woman and non-Muslim to be a president ${ }^{20}$.

Digital information technology has become known in pesantrens since the expansion of the internet. The presence of the internet facilitates communication without any distant in the pesantren. The virtual pesantren ${ }^{21}$ adds an alternative for netizen santri who cannot participate in face-to-face learning, but the problem is that technology is not value-free. Therefore, it is necessary to be selective in choosing media channels to not get trapped in a blind fanatical religious system that does not lead to an improvement. Before the internet entered the pesantren massively, there were actually several digital tools used for learning system in pesantrens. It can be seen how in the past the pesantrens still used rubu' to calculate the beginning of the month (hilal) which is often known as the computation system. However, with the existence of digital tools, astronomy lessons are now starting to be assisted by various digital tools, such as digital cameras, digital calculators to support the syn, cos, $\mathrm{tg}$, cotg calculation algorithm, and etc so that the learning resources in pesantrens, in that case, already accommodate the hybrid word view or dual system. The learning progress use printed books, analogue and digital tools to understand astronomical problems. The use of digital tools in determining the date of 1 Shawwal has also become an arena for a debate and inevitably also brings about certain Islamic ideologies or organizations.

The role of digital technology must be further elaborated on in the development of education in pesantrens because the current digital era has taken into account that what santris, who are born in the digital native era, face is very different from the mindset of the ustadz, who may have been born in the digital immigrant era, and to what extent have the pesantren salaf (traditional) accommodated the role of digital tools in the learning system, especially during the Covid 19 pandemic by considering santris

${ }^{17}$ According to some Kiai, the method mentioned above is not ethical enough for santris to do as stated by KH. Bahauddin Nursalim (Gus Baha') that he would not give a certificate to santri who desired it but did not want to come to the recitation place in person. According to him, the certificate gotten through YouTube or social media is classified as not valid.

18 Muhammad Nida Fadlan, "Digitalizing and Cataloging Islamic Manuscripts in Pesantren," Studia Islamika 19, no. 1 (2012).

19 Ja" far, "Literasi Digital Pesantren: Perubahan Dan Kontestasi."

20 Fazlul Rahman, "Digital Media Literacy for the Better Santri: Reconsidering the Power of Internet for the Students of Traditional Pesantren," Proceedings of International Conference on $D a^{\prime \prime}$ wa and Communication 1, no. 1 (November 5, 2019): 110-118, accessed June 13, 2020, http:// proceedings.uinsby.ac.id/index.php/ICONDAC/article/view/282.

${ }_{21}$ Mukhibat Mukhibat, "Virtual Pesantren Management in Indonesia: In Knowing Locality, Nationality, and Globality," Dinamika Ilmu: Jurnal of Education 20, no. 1 (2020): 123-132. 
since March 2019 have not been able to study intensively as in the days before the pandemic. The Covid 19 pandemic has hit the entire world population since the beginning of 2019. The Government of the Republic of Indonesia has announced to carry out "citagarmas" habits, namely conducting health protocols at all times by always washing hands, maintaining distance between individuals, and having to use masks in daily activities.

Learning progress in several pesantrens has started to be held with various creativeness so that all santris can learn both from home and from madrasah. Pesantren salaf organize a dual system learning system both offline and online. This is because there are a number of students departing from home or known as santri non-mukim (non-settlement). Santri mukim (living inside the pesantren) can take part in direct learning in class with the ustadz in pesantren, while santri non-mukim can participate online from their homes. Learning methods for santris mukim and santris non-mukim are actually unfair in receiving the material. Ideally, in this condition, all santris are obliged to stay temporarily or permanently to make them more focus in their activities in the pesantren. Therefore, santris can be localized to anticipate the possibility of spreading the virus from outside the pesantren.

Pesantren Virtual can be a substitute for the real of pesantren in the current pandemic era. Throughout the history of pesantrens from its inception until now, from its written and oral culture, to digital culture, issues have not yet been resolved for discussion. Several things are considered difficult to change from the old tradition of pesantren, because the schedule of activities are too tight and the residents of the pesantren sometimes exceeds the capacity (overload). One of the scientific traditions of pesantrens has become a trade mark in itself with its uniqueness, such as reciting kitab kuning by giving meaning (filling a bare book or kitab kuning) using a pen with ink from the powdered stone batteries. However, there is available now many pen products with special sizes.

\section{Maktabah Syu>mila NU Fi>ha and Maktabah Sya>milah in a Digital Contestatition in Pesantren}

The world of technology is developed to help ease the burden of human tasks. Developing technology is not value free, as Arthur22 said that software is as an ideology ${ }^{23}$. This picture can be seen on how rampant the use of technology as a means or media of $d a^{\text {" }}$ wah (spreading Islamic Value), starting from conventional, mainstream to modern models. In the past, television and radio were popular media for $d a^{\prime \prime}$ wah. As the development of technology entered the digital era, the media streaming began to be displaced by digital media. There are many choices of digital media to convey information to the public, including the massive use of social media such as Facebook, Instagram, Twitter, Telegram, WhatsApp, YouTube, and various other digital applications. Digital applications are one of the media technology tools that are very easy to use for the spread of certain ideologies.

Islamic digital applications such as maktabah syu>milah $N U$ fi $>$ ha and many others seem to have escaped the view of scholars and researchers. The birth of this application

22 Arthur Kroker, ed., Critical Digital Studies: A Reader, 2. ed. (Toronto: Univ. of Toronto Press, 2013), 12.

${ }^{23}$ Luis F. Alvarez León and Jovanna Rosen, "Technology as Ideology in Urban Governance," Annals of the American Association of Geographers 110, no. 2 (March 3, 2020): 497506, accessed March 2, 2021, https://doi.org/10.1080/24694452.2019.1660139. 
was inspired by an application called al-maktabah asy-sya>milah. Syamilah is an application made in Saudi Arabia that contains thousands of classic books by Arabic scholars. For more complete information on downloading and installing the software, visit shamela.ws (maktabah sya>milah), arrawdah.com, al-waqfea.com, and almesykat.com. There is the dominance of classic book uploads by Wahhabi scholars such as Muhammad bin Abdul Wahhab, Albani, Uthaimin, Ibn Taymiyyah, BinBaz on the shamela.ws page. Therefore, it is presumed that al-maktabah asy-sya>milah (syamilah; shamela) is an application to carry Wahhabi's missions ${ }^{24}$.

Those exposure led to the emergence of a new digital application called almaktabah syu>mila NU fi>ha which was created with the aim of fortifying pesantren from radical and transnational understandings. Pesantren Salaf are synonymous with the tradition of using kitab kuning in learning activities. Over time, information and communication technology led to changes in the culture of printed books to digital books with the digitization of kitab kuning or often known as e-books (electronic books). After being digitized, then it was input into an application (platform). The application becomes a software containing a compilation of books (classical books) which have been translated into digital format, which later is called al-maktabah asy-sya>milah, almarja "al-kubra, al- maktabah al-turmusy, maktabah syu>mila NU fi>ha, and so on.

Islamic digital application called Maktabah Syamilah version 4.0 which was published in August 2020. This application was first developed in 2005 by multaqa alhadith, al-mesykat, al-waqfea, and shamela.ws. The menu display is simpler than the previous version (version 3.47). The software can be downloaded for free and installed easily on the old shamel.ws, which when opened in the Android application, the language of instruction changes automatically according to the desired language.

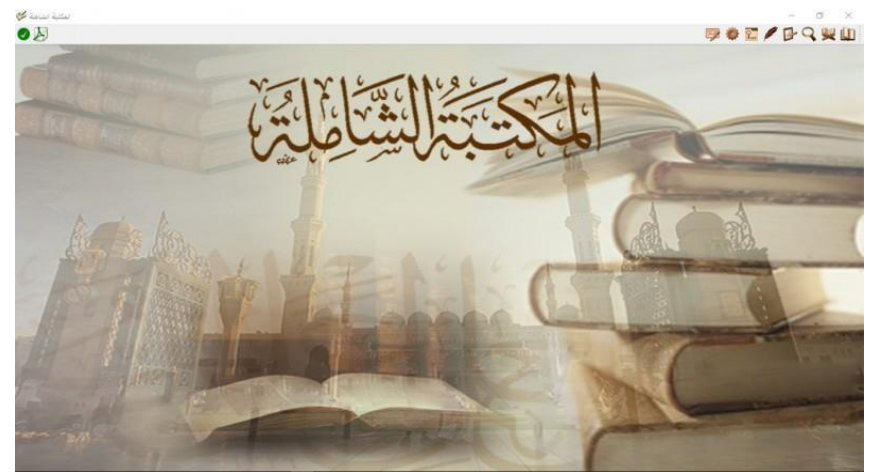

Figure 1: Home of al-Maktabah asy-Syamilah version 4.0

Al-Maktabah asy-sya>milah is digitalization products from Saudi Arabia while alMaktabah Syu>mila NU fi>ha is the work of a santri at the Pesantren Assalafiyyah in Mlangi, Yogyakarta, which was built in 2007. The application contains kitab kuning in the style of a pesantren. which has been digitized and also contains articles related to Nahdlatul Ulama (NU). When viewed from the amount of content and the ability of the software as a means of searching for syu>mila $N U$ is not comparable to sya>milah. Sya>milah is a software having retrieval capabilities of good information because it is also equipped with a search column using advance search using bolean logic of AND, OR, and NOT or (in Arabic: WA, AU, and LAISA) while in Syu>mila NU is not equipped with a search column as a means of retrieval.

${ }^{24}$ Nur Khalik Ridwan, Sejarah Lengkap Wahhabi (Yogyakarta: IRCiSoD, 2020). 


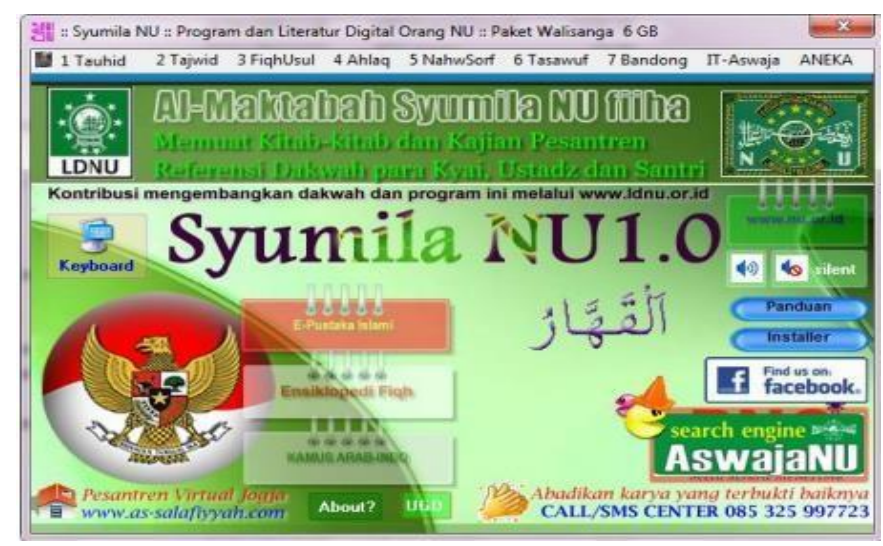

Figure 2: The homepage of the al-Maktabah Syumila NU Fiha Application

Maktabah syu>mila NU fi>ha is a kitab kuning software taught in pesantren salaf. This application was made in the aim of utilizing the potential of information and communication technology for media of $d a^{\prime \prime}$ wah in accordance with the demands of the digital era, and the most important thing is to provide a fortress for pesantren from the influence of vulnerable applications bringing radical, transnational, preaching traditions, puritans, and apolitic.

Table 2: Comparison between Maktabah Syamilah and Maktaba Syumila NU Fiha

\begin{tabular}{|c|c|c|c|}
\hline No & Elements & Syamilah & Syumila \\
\hline 1 & Origin & Saudi Arabia & Indonesia \\
\hline 2 & Interface Language & Arabic Language & $\begin{array}{l}\text { Indonesian } \\
\text { Language }\end{array}$ \\
\hline 3 & Dominant Kitab & $\begin{array}{l}\text { The Book of Arabic } \\
\text { Ulama Works }\end{array}$ & $\begin{array}{l}\text { The books taught by } \\
\text { the salaf pesantren } \\
\text { are the works of } \\
\text { Ulama Nusantara } \\
\text { which are mu'tabar, } \\
\text { and ala Aswaja NU }\end{array}$ \\
\hline 4 & Uniqely & $\begin{array}{l}\text { Contains thousands } \\
\text { of classical Islamic } \\
\text { books which can also } \\
\text { be accessed online at } \\
\text { shamela.ws }\end{array}$ & $\begin{array}{lr}\text { Digitizing } & \text { NU's } \\
\text { Guidebooks, } & \text { Pethuk } \\
\text { Books, } & \text { Islamic } \\
\text { boarding } & \text { schools, } \\
\text { and others } & \end{array}$ \\
\hline 5 & Donation & Awqaf al-Rajh & $\begin{array}{l}\text { Dermawan } \\
\text { (simpatisan) }\end{array}$ \\
\hline 6 & Socialization & $\begin{array}{l}\text { Indonesian students } \\
\text { in Arab, Mesir, } \\
\text { Jepang (Nuhon) }\end{array}$ & $\begin{array}{lr}\text { Muktamar NU in } \\
\text { Jombang, } & \text { Social } \\
\text { Media, Blog } & \end{array}$ \\
\hline 7 & Familiarity & More Familiar & No Familiar \\
\hline 8 & Developed by & $\begin{array}{l}\text { Multaqa ahl al-hadis, } \\
\text { pesantrenvirtual.com, } \\
\text { almeskat, al-waqfea, }\end{array}$ & $\begin{array}{l}\text { IWAF, Students of } \\
\text { Boarding School of } \\
\text { Assalafiyyah, }\end{array}$ \\
\hline
\end{tabular}




\begin{tabular}{|c|c|c|c|}
\hline \multirow{4}{*}{9} & \multirow[b]{2}{*}{ Containt } & al-shamela & Mlangi, Yogyakarta \\
\hline & & Arab Studies & Arab Studies, Article \\
\hline & & & about NU \\
\hline & & & (Nahdlatul Ulama), \\
\hline & & & $\begin{array}{l}\text { art, and Islamic } \\
\text { culture. }\end{array}$ \\
\hline 10 & Sustainibility & Sustainable, update, & Out of date, stagnant \\
\hline & & $\begin{array}{l}\text { shamela.ws and } \\
\text { app.turath.io }\end{array}$ & \\
\hline 11 & Published & 2007 & 2012 \\
\hline 12 & Format & Arabic Text & Arabic \\
\hline & & & Indonesian \\
\hline & & & $\begin{array}{l}\text { Audio, images, and } \\
\text { video. }\end{array}$ \\
\hline 13 & Retrieval Systems & Browse or hasib with & Without seraching \\
\hline & & boolean logic "Wa, & colom. \\
\hline & & Au, Laisa". & \\
\hline 14 & Ideology & Wahabism & Aswaja NU \\
\hline
\end{tabular}

Source: Researcher's synthesis

Digital religious studies has emerged as a research field that has evolved along with the development of the internet over the past three decades. Digital religious studies have reflected research strategies, approaches to technology, and understanding of the impact of digital media on culture in this broader context. The field of digital religion research can be characterized by four waves of scientific inquiry, which are discussed in this article.

Mapping the growth of digital religious studies is by exploring common themes, theories, and methodological approaches related to this field of study. In addition, by highlighting three general areas of inquiry, namely the idea of religious identity, authority, and community shows how religion is lived and understood in various digitally mediated contexts. It provides an overview of how various actors and religious groups have negotiated spiritual activity and the use of technology in areas where intersect online and offline in their lives. Comprehensively, this article will provide a critical assessment of the current state of digital religious studies 25 .

Digital religion is a technological and cultural space that emerges when it comes to how online and offline religious fields have been combined or integrated. Like all other aspects of 21st century life, the divisions between offline and online are increasingly blurred. For some adherents, complementing or even replacing offline religious communities and practices with online as an alternatives and extensions is old news. Covid-19 has changed religion. Religion is always changing. There has been an acceleration of innovation in digital religion caused by Covid-19 around the world.

${ }^{25}$ Heidi A. Campbell and Giulia Evolvi, "Contextualizing Current Digital Religion Research on Emerging Technologies," Human Behavior and Emerging Technologies 2, no. 1 (2020): 5-17, accessed October 7, 2020, https://onlinelibrary.wiley.com/doi/abs/10.1002/hbe2.149. 
This innovation is worthy of sociological analysis 26 .

As was conducted by Pesantren Salafiyyah Syafi'iyyah Sukorejo Situbondo which carried out activities of al-Masa> ,il offline (outside the network) then when the Covid-19 pandemic hit, these activities were online or in a network. The use of digital applications such as maktabah sya>milah is certainly very helpful for these activities without having to meet face to face (offline) with crowds. Simply by using the zoom meeting application or google meet, these activities can take place.

Presentation materials are also sufficient by using a presentation share, so the material for bahth al-masa> ,il can be read simultaneously by multi-user and ubiquitely. Digital applications such as maktabah sya>milah, maktabah kubro, maktabah syu>mila NU $f i>h a$ are very helpful in finding certain information or propositions. Information technology provides solutions to communication problems in religion. The synergy of technology (science) and religion (Islamic studies) is an evidence of the integrated interconnection of multi-disciplinary, interdisciplinary, and scientific transdisciplinary. Therefore, there is no longer mono-disciplinary and dichotomy of general science and religious knowledge.

\section{E. Pesantren's Response to the Use of Digital Classic Book Applications}

According to Mustofa, he states that the use of mu" tabar (valid) kitab kuning tends to be ideological and not open to other thoughts so that it seems to deify the classical texts 27 . This opinion also needs to be criticized that not all pesantren are like that. Pesantren Salafiyyah Syafi" iyyah Sukorejo Situbondo is a boarding school providing freedom of thought so that not only one source of reference is mu'tabar, even the opinions of western philosophers are studied ${ }^{28}$. However, pesantren salaf still maintains its scientific tradition of ahl al-sunnah wa al-jama> "ah as a part of the dynamics of religious studies which will further develop with the advent of the digital era, thus, it will continue into the next study, namely the development of digital religious studies. The digitization is in order to provide the widest possible access to academician more easily and cheaply obtaining information sources.

Digital applications have become a new authority in supporting the smoothness of learning in pesantrens. The presence of this digital authority needs to be taken into account when all activities must be carried out from home, the digital platform will greatly assist the learning process. Some pesantren salaf continue to carry out learning activities in a safe and controlled manner using online information and communication technology. This technology is in the form of using digital devices that are portable and practical.

The study of digital religion is to examine the influence of religion and digital media on one another. In recent decades, scholars of media and religion have paid increasing attention to the use of new media. Along with the development of the internet that has become embedded in everyday life, digital media is increasingly

${ }^{26}$ Hazel O" Brien, "What Does the Rise of Digital Religion during Covid-19 Tell Us about Religion" s Capacity to Adapt?," Irish Journal of Sociology 28, no. 2 (August 1, 2020): 242-246, accessed October 7, 2020, https://doi.org/10.1177/0791603520939819.

27 Mustofa Mustofa, "Kitab Kuning Sebagai Literatur Keislaman Dalam Konteks Perpustakaan Pesantren," Tibanndaru: Jurnal Ilmu Perpustakaan dan Informasi 2, no. 2 (2019): 12.

28 Hatim Gazali and Abd Malik, "Pesantren and the Freedom of Thinking: Study of $\mathrm{Ma}$,"had Aly Pesantren Sukorejo Situbondo, East Java, Indonesia," Al-Jami" ah: Journal of Islamic Studies 47, no. 2 (December 20, 2009): 295-316, accessed September 26, 2020, https://www.aljamiah.or.id/index.php/AJIS/article/view/99. 
informing religious practices, things that adherents do in affirming their beliefs and expressing their religious identity, things that adherents do to show their affiliation with religion or religious community ${ }^{29}$.

Pesantrens have known digital technology since the massive expansion of the internet in the mid-2000s. The use of digital technology in pesantrens is not limited to internet-based electronic devices, but there are various tools used to digitalize without using internet access. Some of them are the use of digital tools, i.e. the use of digital calculators complete with algorithmic functions to support the calculation of $\sin$, cos, $\mathrm{tg}$, cosine, and etc. In addition to calculating tools for math and physics lessons, this tool is also needed for calculating tools to determine the change in the beginning of the new month in astronomy lessons. Before this digital technology existed, pesantrens still used a quarter circle-shaped wooden manual tool, later known as rubu" in Indonesian which means a quarter circle.

The tool contains arithmetic table information in traditional astronomy to determine the start of prayer times. Literacy like this has rarely surfaced in contemporary scientific discourse because the counting system for determining the beginning of prayer times has used digital technology in the form of a digital wall clock, permanently installed on the wall of the pesantren's mosque ${ }^{30}$.

Pesantren Assalafiyyah Mlangi, Sleman, Yogyakarta has also begun to use various administrative service of computer application-based online and offline to eliminate the image of pesantren salaf which is identically to manual and analog technology. Even the differences between traditional and modern pesantren in terms of responding to digital technology are slightly thin. However, the categorization of traditional and modern pesantren is not only limited to the use of digital technology, but more importantly in learning process in pesantren salaf, they still keep using Kitab Kuning as a learning medium by applying the sorogam, wetonan, and bandongan methods. In contrast to pesantren modern which organize learning with white books and translations. Pesantrens in the era of digital technology, as they currently have, still have a skeptical tendency in responding to the presence of digital applications in pesantrens that are seen as something considered as syubhat ${ }^{31}$. Many practices of using digital devices in pesantren have contributed to improve administrative and learning services. Information and communication technology have contributed to a practical system in financial administration services of pesantrens, such as a transaction system without using cash but with a controlled credit card in spending the use of pocket

${ }^{29}$ Heidi A. Campbell and Forrest Rule, "The Practice of Digital Religion," in Handbuch Soziale Praktiken und Digitale Alltagswelten, ed. Heidrun Friese et al. (Wiesbaden: Springer Fachmedien, 2020), 363-371, accessed October 7, 2020, https://doi.org/10.1007/978-3-65808357-1_38.

30 There are many things related to the expansion of digital technology in pesantren salaf mainly because pesantrens have been managed traditionally. The use of computer-assisted tools has been widely applied. Pesantren Darul Huda Mayak Tonatan, Ponorogo is a pesantren salaf al-hadisy which has begun to adopt a lot of digital technology. One of the highlights is the use of megatron in every major event. Pesantren no longer uses a backdrop or background for activities using banners or writing manually but has used digital electronic devices in the form of megatron technology to make backdrops in a practical, prestigious, and elegant manner.

${ }^{31}$ Faiz In" amurrohman, "Kesyubhatan TIK: Sisi Gelap Dan Terang Penggunaan TIK Pada Literasi Digital Keislaman Dalam Perspektif Pondok Pesantren Salaf" (Thesis, Universitas Islam $\begin{array}{llll}\text { Indonesia, 2019), } & \text { accessed 2019, }\end{array}$ https://dspace.uii.ac.id/handle/123456789/16086. 
money.

Additionally, other digital tools used in the study of astronomy in pesantren which is used to rely on manual tools in calculating the beginning of the month of Qomariah using a digital calculator equipped with calculating algorithms of sin, cos, tangent, co-tangent, and etc; and determine the direction of Qibla in the traditional way is now assisted by compass tools using a digital compass.

Digital sources of information about classical sources in Islam have flooded the cyberspace. The digital information boom challenges pesantren to make good use of it. It all depends on the ability and willingness to learn it. Indeed, not everyone is able to understand contents in Arabic, but information technology has also provided its services in multi-language so that they can easily translate them. The following is a list of some Arabic literature containing classical Islamic sources in digital format.

Table 3. list of some Arabic literature containing classical Islamic sources in digital format

\begin{tabular}{ll} 
No. Digital Islamic Source Address \\
\hline http://shamela.ws/ \\
https:// bookboon.com/ \\
http://www.voced.edu.au/ \\
http://lib.alharamain.gov.sa/ \\
http://www.wdl.org/ar/ \\
http:// publications.kacst.edu.sa/ \\
http://www.kfnl.org.sa \\
https://www.muslim-library.com \\
http:// repository.ksu.edu.sa \\
https://www.baenebooks.com \\
http://open.umn.edu/opentextbooks/ \\
http://www.digitalbookindex.org \\
http://www.freebookcentre.net/ \\
http://www.freeengineeringbooks.com/ \\
https://waqfeya.com/ \\
http:// kadl.sa/ \\
http://www.alwaraq.net \\
http://www.almotanabbi.com
\end{tabular}

Source: Author Synthesis ${ }^{32}$

Pesantren Salaf still view the use of kitab kuning digital software as not an urgent. This is because santris still need to focus on mastering the kitab kuning. Moreover, some consider it taboo and syubhat in response to the presence of kitab kuning digital application at pesantrens. The use of digital applications can actually be positioned as a supporter to learn smoothly based on printed kitab kuning. The presence of digital applications is not in a position as a replacement but as a supporting tool. The challenge of pesantrens in the midst of the development of Information and Communication Technology demands that students be able to be smart and wise in responding to their presence. In line with the principle, students must be dynamic with the times and be able to sort and select new information sources for information 
technology products 33 .

Pesantren Hidayatul Mubtadi'in is a pesantren salaf that still adheres to the tradition of the printed of kitab kuning which does not allow students to use kitab kuning digital application as a means of retrieval of information. Although in fact there has been previous research which says that in the activities of bahth al-zaman > ,il have used digital media, as also stated in Khamim's research ${ }^{34}$. Printed media and digital formats in the digital era actually exist in a complementary position (co-existence).

\section{F. Conclusion}

Pesantren Salaf still cannot fully accept the presence of the Maktabah syamilah and syumila NU software as a means of searching for information on digital classical books. Pesantrens are still skeptical about the use of digital applications because they are feared that they will have a negative impact on the learning system of students who have focused on kitab kuning system. Pesantren Hidayatul Mubtadi'in Lirboyo Kediri represents a skeptical response. Pesantren Assalafiyyah Mlangi, Sleman, Yogyakarta tends to be neutral, a pesantren salaf that can accept the presence of digital applications but still have not used them optimally, while Pesantren Salaf Syafi'iyyah Sukorejo, Situbondo is optimistic, a pesantren salaf gives freedom to santris in using digital technology such as the two applications. The problem of the contestation of the two digital applications is that santris should be given additional knowledge to be more selective in choosing information sources by sticking to the principle of maintaining the "a relevant old tradition" and adopting new "better" knowledge (al-muhafadlatu ala qadimi al-shalih wa al-akhdzu bil jadid al-ashlah) because santris must always be dynamic in all times and places (shalih likulli zaman wal makan). Pesantren's response to the phenomenon of using kitab kuning digital application is still not urgent for those who are pessimistic, then take a neutral attitude (between pessimism and optimism), while an optimistic attitude provides freedom in obtaining digital information.

\section{REFERENCE}

Abdullah, Amin. Multidisiplin, Interdisiplin, E Transdisiplin: Metode Studi Agama E Studi Islam Di Era Kontemporer. Cet.ke-2. Yogyakarta: IB Pustaka, 2020.

Anwar, Ali. "Dinamika Keilmuan Di Pesantren Lirboyo Kediri." Al-Riwayah: Jurnal Kependidikan 7, no. 1 (2015): 31-44.

Baig, Fatima Zafar, Wajeeha Yousaf, Fareeha Aazam, Sarah Shamshad, Iqra Fida, and Muhammad Zammad Aslam. "Power, Ideology and Identity in Digital Literacy: A Sociolinguistic Study." International Journal of English Linguistics 9, no. 4 (July 3, 2019): 252. Accessed January 2021. http://www.ccsenet.org/journal/index.php/ijel/article/view/0/40015.

Berman, Saul J. "Digital Transformation: Opportunities to Create New Business Models." Strategy E Leadership 40, no. 2 (March 2, 2012): 16-24. Accessed February

33 Ritonga, Lahmi, and Hakim, "The Existence of Yellow Books (Kitab Kuning) as the Sources of Islamic Studies at Islamic Boarding Schools Within the Industrial Revolution Dialectics."

${ }^{34}$ Interview with Ayaq (Ketua Lembaga Bahth al-Masa>" il) Pondok Pesantren Hidayatul Mubtadi" in Lirboyo, Kediri, 15 Nopember 2019. 
https://www.emerald.com/insight/content/doi/10.1108/10878571211209314/f ull/html.

Brien, Hazel O". "What Does the Rise of Digital Religion during Covid-19 Tell Us about Religion"s Capacity to Adapt?" Irish Journal of Sociology 28, no. 2 (August 1, 2020): 242-246. Accessed October 7, 2020. https:// doi.org/10.1177/0791603520939819.

Campbell, Heidi A., and Giulia Evolvi. "Contextualizing Current Digital Religion Research on Emerging Technologies." Human Behavior and Emerging Technologies 2, no. 1 (2020): 5-17. Accessed October 7, 2020. https://onlinelibrary.wiley.com/doi/abs/10.1002/hbe2.149.

Campbell, Heidi A., and Forrest Rule. "The Practice of Digital Religion." In Handbuch Soziale Praktiken und Digitale Alltagswelten, edited by Heidrun Friese, Marcus Nolden, Gala Rebane, and Miriam Schreiter, 363-371. Wiesbaden: Springer Fachmedien, 2020. Accessed October 7, 2020. https://doi.org/10.1007/978-3-65808357-1_38.

Chapco-Wade, Colleen. "Digitization, Digitalization, and Digital Transformation: What's the Difference?" Medium. Last modified October 21, 2018. Accessed February 12, 2020. https://medium.com/@colleenchapco/digitizationdigitalization-and-digital-transformation-whats-the-difference-eff1d002fbdf.

Fadlan, Muhammad Nida. "Digitalizing and Cataloging Islamic Manuscripts in Pesantren." Studia Islamika 19, no. 1 (2012).

Gazali, Hatim, and Abd Malik. "Pesantren and the Freedom of Thinking: Study of Ma „had Aly Pesantren Sukorejo Situbondo, East Java, Indonesia." Al-Jamiah: Journal of Islamic Studies 47, no. 2 (December 20, 2009): 295-316. Accessed September 26, 2020. https://www.aljamiah.or.id/index.php/AJIS/article/view/99.

In' amurrohman, Faiz. "Kesyubhatan TIK: Sisi Gelap Dan Terang Penggunaan TIK Pada Literasi Digital Keislaman Dalam Perspektif Pondok Pesantren Salaf." Thesis, Universitas Islam Indonesia, 2019. Accessed December 30, 2019. https://dspace.uii.ac.id/handle/123456789/16086.

Ja" far, Ali. "Literasi Digital Pesantren: Perubahan Dan Kontestasi." Islamic Review: Jurnal Riset dan Kajian Keislaman 8, no. 1 (2019): 17-35.

Khamim. Mengkaji Hadis Di Pesantren Salaf. Kediri: STAIN Kediri Press, 2015.

Kroker, Arthur, ed. Critical Digital Studies: A Reader. 2. ed. Toronto: Univ. of Toronto Press, 2013.

León, Luis F. Alvarez, and Jovanna Rosen. "Technology as Ideology in Urban Governance." Annals of the American Association of Geographers 110, no. 2 (March 3, 2020): 497-506. Accessed March 2, 2021. https://doi.org/10.1080/24694452.2019.1660139.

Lin, Hong. "From Paper to Digital: Undergraduate Students" Perceptions with Open Educational Resources." 1207-1215. Association for the Advancement of Computing in Education (AACE), 2019. Accessed February 26, 2021. https://www.learntechlib.org/primary/p/207798/.

Miller, Boaz. "Is Technology Value-Neutral?" Science, Technology, \& Human Values 46, no. 1 (January 1, 2021): 53-80. Accessed March 2, 2021. https://doi.org/10.1177/0162243919900965. 
Mukhibat, Mukhibat. "Virtual Pesantren Management in Indonesia: In Knowing Locality, Nationality, and Globality." Dinamika Ilmu: Jurnal of Education 20, no. 1 (2020): 123-132.

Mustofa, Mustofa. "Kitab Kuning Sebagai Literatur Keislaman Dalam Konteks Perpustakaan Pesantren." Tibanndaru: Jurnal Ilmu Perpustakaan dan Informasi 2, no. 2 (2019): 1-14.

Pangrazio, Luciana. "Reconceptualising Critical Digital Literacy." Discourse: Studies in the Cultural Politics of Education 37, no. 2 (March 3, 2016): 163-174. Accessed January 4 , 2021. https://www.tandfonline.com/doi/full/10.1080/01596306.2014.942836.

Rahman, Fazlul. “Digital Media Literacy for the Better Santri: Reconsidering the Power of Internet for the Students of Traditional Pesantren." Proceedings of International Conference on Da'wa and Communication 1, no. 1 (November 5, 2019): 110-118. Accessed June 13 , 2020. http:// proceedings.uinsby.ac.id/index.php/ICONDAC/article/view/282.

Ridwan, Nur Khalik. Sejarah Lengkap Wahhabi. Yogyakarta: IRCiSoD, 2020.

Ritonga, Mahyudin, Ahmad Lahmi, and Rosniati Hakim. "The Existence of Yellow Books (Kitab Kuning) as the Sources of Islamic Studies at Islamic Boarding Schools Within the Industrial Revolution Dialectics." Int. J. Psychosoc. Rehabil 24, no. 8 (2020): 3516-3523.

Shults, F. LeRon. "When Science Meets Religion: Enemies, Strangers or Partners?" Theology Today 58, no. 3 (October 2001): 434-435. Accessed February 27, 2021. http://journals.sagepub.com/ doi/10.1177/004057360105800318.

Tabrizi, Behnam, Ed Lam, Kirk Girard, and Vernon Irvin. “Digital Transformation Is Not About Technology" (n.d.): 6.

Verina, Natalja, and Jelena Titko. "Digital Transformation: Conceptual Framework." In Proc. of the Int. Scientific Conference "Contemporary Issues in Business, Management and Economics Engineering" 2019", Vilnius, Lithuania, 9-10, 2019.

Wahid, Abdul, and Marizakertaningtyas Marizakertaningtyas. "Efektifitas Software Dan Aplikasi Syumila Nu 1.0 Untuk Penguatan Ideologi Pesantren an-Nur AlHuda Dari Ancaman Paham Islam Transnasional." JURNAL TEKNOLOGI INFORMASI: Teori, Konsep, dan Implementasi 9, no. 1 (2018): 10-16.

Wiener, Antje. A Theory of Contestation. SpringerBriefs in Political Science. Berlin, Heidelberg: Springer Berlin Heidelberg, 2014. Accessed July 30, 2019. http:/ / link.springer.com/10.1007/978-3-642-55235-9.

Wimelius, Henrik, Lars Mathiassen, Jonny Holmström, and Mark Keil. “A Paradoxical Perspective on Technology Renewal in Digital Transformation." Information Systems Journal 31, no. 1 (2021): 198-225. Accessed March 2, 2021. https://onlinelibrary.wiley.com/doi/abs/10.1111/isj.12307.

“74 Maktabah Raqmiah Maftuhah Min Asyhur Al-Maktabah Al-Iliktruniah.” Darul Qurra, n.d. Accessed April 9, 2020. http:/ / darulqurra.edu.pk/74.

"Hasil Pencarian - KBBI Daring." Accessed January 12, 2021. https://kbbi.kemdikbud.go.id/entri/kontestasi. 